\title{
Influence of service life, strength and cement type on life cycle environmental performance of concrete
}

\section{Influência da vida útil, resistência característica e tipo de cimento no desempenho ambiental do ciclo de vida do concreto}
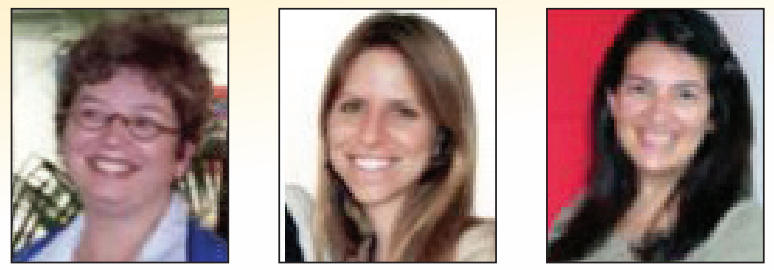

M. G. SILVA a

margomes.silva@gmail.com

M. R. M. SAADE

marcellarms@hotmail.com

V. GOMES b

vangomes@gmail.com

\begin{abstract}
This paper assesses environmental loads of concretes made with Portland blended cements containing different proportions of ground granulated blast furnace slag (ggbs) as clinker replacement and with characteristic compressive strength ranging from 25 to $60 \mathrm{MPa}$. Impact assessment method CML 2001 v. 2.04 and Life Cycle Assessment platform SimaPro 7.3 respectively supported calculations in terms of environmental impact categories and of a set of life cycle indicators. Service life, estimated via Life 365 v.2.1 software, is tested as a functional unit normalizer for environmental assessment of concrete elements through application to the embodied $\mathrm{CO}_{2}$ indicator. Increased fractions of ggbs in Portland cement reduce concretes' life cycle environmental loads as indicated by all metrics but blue water footprint. Effects of clinker replacement on the indicators are discussed. Service life consideration proved to add coherence to concrete's environmental, functional and technical quality interpretation.
\end{abstract}

Keywords: cement; concrete; service life; environmental indicators; life cycle assessment.

\section{Resumo}

Este trabalho objetiva avaliar as cargas ambientais de concretos fabricados com cimento Portland contendo diferentes proporções de escória granulada de alto-forno (egaf) em substituição ao clínquer e com resistência carcaterística variando de 25 a $60 \mathrm{MPa}$. O método de avaliação de impactos CML 2001 v. 2.04 e a paltaforma de Avaliação de Ciclo de Vida SimaPro 7.3 deram suporte ao cálculo das categorias de impacto e de um conjunto de indicadores de ciclo de vida, respectivamente. A vida útil, estimada por meio do software Life 365 v.2.1, é testada como unidade funcional normalizadora para a avaliação ambiental dos elementos de concreto por meio da aplicação do indicador $\mathrm{CO}_{2}$ incorporado. Os valores dos indicadores, com exceção da pegada de água azul, evidenciam que o aumento das frações de egaf no cimento Portland reduz as cargas ambientais do ciclo de vida do concreto. Discutem-se os efeitos da substituição do clínquer sobre os indicadores. Aconsideração da vida útil provou agregar coerência à interpretação da qualidade ambiental, funcional e técnica do concreto.

Palavras-chave: cimento; concreto; vida útil; indicadores ambientais; avaliação do ciclo de vida. 


\section{Introduction}

In 2011, Portland cement's annual global production reached the value of 2.8 billion tones (Schneider et al [1]). As a result, cement making currently responds for approximately $5 \%$ of global anthropogenic carbon emissions (Huntzinger; Eatmon [2]). That percentage is increasing rapidly, considering that cement and concrete manufacture rises at a rate that is higher than the reduction of carbon emissions (CSI [3]). Portland cement global production is expected to increase by 2.5 times between 2005 and 2050, with a considerable amount of that growth happening in developing countries (CSI [4]).

Roughly half of cement making $\mathrm{CO}_{2}$ is emitted during decarbonation of limestone into calcium oxide, which will react with silica and aluminum oxide to produce Portland clinker. Substituting supplementary cementitious materials (SCMs) for clinker in cement has therefore a great potential to lower cement and concrete's carbon footprint, as well as consumption of virgin material, embodied energy and other impacts associated to clinker manufacturing. Technical advantages of replacing clinker with ground granulated blast furnace slag (ggbs), for example, have been demonstrated by several studies, including those of Silva [5], Silva et al [6], and Silva [7]. Isaia and Gastaldini [8] showed that the environmental, technical and economical gains are proportional to the amount of clinker replaced. Similarly, Buffenbarger [9] states that the embodied energy of concrete mixtures is directly proportional to their cement content and Van Geem [10] estimates that for every $1 \%$ replacement of cement with SCMs the embodied energy of concrete is reduced by $0,7 \%$. Comparable reference values for other environmental indicators applied to concrete are still scarce.

In Brazil, ggbs has been used as clinker replacement in Portland cement manufacturing for over 50 years. According with their ggbs content by mass, two types of blended cements are standardized: CP II-E-32, with up to $35 \%$ of ggbs (ABNT [11]) and CP III-32, with up to $70 \%$ of ggbs (ABNT [12]).

This paper aims at estimating some environmental loads associated to concretes using different types of cement and with different characteristic compressive strengths (fck). It also investigates usefulness of service life, estimated via Life 365 v.2.1 software, as a functional unit normalizer for environmental assessment of concrete elements. Impact assessment method CML 2001 v. 2.04 and Life Cycle Assessment platform SimaPro 7.3 respectively supported calculations in terms of environmental impact categories and of a set of life cycle indicators.

Life cycle environmental indicators are commonly used to describe the resource intensity and other environmental loads associated to a given product or process. Great attention is paid to embodied energy and carbon, but, with the crescent demand for environmental product declarations (EPDs) in all business sectors, the European Standard EN 15804 [13] was established to determine the core rules for declarations referring to construction products. From all environmental parameters listed in that standard, primary energy, global warming potential (GWP), ozone depletion potential (ODP), acidification potential (AP), eutrophication potential (EP) and photochemical ozone creation potential (POCP) seem to be the most usually found. Contrastingly, though also listed as potential items in EPDs of construction products and fundamental to provide a thorough understanding of their impacts, water consumption and some metric of mineral resources depletion are seldom used.
The European Committee for Standardization Technical Committee dedicated to developing standards on sustainability of construction works (CEN TC 350) recommends using the abiotic depletion potential (ADP). However, different forms of APD can be used, depending on the type of reserve and the available extraction rates. In the construction sector, ADP might be adapted to describe local depletion of natural resources (i.e. non-renewable raw material content) such as gravel and sand (Habert et al. [14]) and be possibly complemented by a recycling indicator, pointed out by RILEM LCA Technical Committee as the only specific indicators needed apart from the generally used environmental life cycle indicators (Roussel [15]). This matter is still a research topic targeted by the specialized scientific community.

\section{Methodology}

Figure [1] summarizes the main steps of this study. Black boxes represent the results obtained. The following items describe each stage more thoroughly.

LCA is divided in three main stages: (i) goal and scope definition, when the study's purpose is defined; (ii) life cycle inventory (LCI) analysis, in which calculations regarding emissions and resource use is carried; and, finally, (iii) environmental impact assessment, in which data regarding emissions and resource use is related to different impact categories, transforming the inventory results into more relevant environmental information.

According to ISO 14044:2006 (ISO [16]), the impact assessment stage is divided in mandatory, and optional sub stages. The mandatory sub stages are classification and characterization. Classification assigns $\mathrm{LCl}$ results to their respective impact categories, and characterization measures the relative contribution of each $\mathrm{LCl}$ result to its impact category, using equivalency factors.

The optional sub stages performed vary across impact assessment methods. Normalization is the only optional sub stage performed by CML 2001 v.2.04, the impact analysis method adopted in this paper. Normalization shows to what extent an impact category contributes to the overall environmental problem, through the division of the impact category value by a "normal" value, which could be, for example, the impact category indicators for a specific region during a year, divided by the number of inhabitants in that specific area (Goedkoop et al [17]). CML 2001 v.2.04 adopts that type of procedure considering the entire planet as the analyzed region. This procedure helps identifying the impact categories with the most - and the least - significant contributions to their respective impacts, reducing the number of environmental issues to be evaluated in detail to provide an environmental profile overview.

\subsection{Data used in this study}

Based upon published data on concrete mix designs with CP IIE-32 and CP III-32 (Silva [5]), and with CP I-S-32 (Regattieri et al [18]), the respective strength (fck) values were entered in concrete mix design graphs to obtain the mix proportions, cement (and clinker) consumption, mortar content and water to dry materials ratio listed in Table [1] for each strength class.

Concrete mixes with CP II-E-32 and with CP III-32 were lab-designed for consistency $70 \pm 10 \mathrm{~mm}$, to avoid unidentified influence of admixtures over the properties investigated by Silva [5]. In concretes with cement CP I-S-32, water-reducing and superplasticizers admix- 


\section{Figure 1 - Research stages diagram}

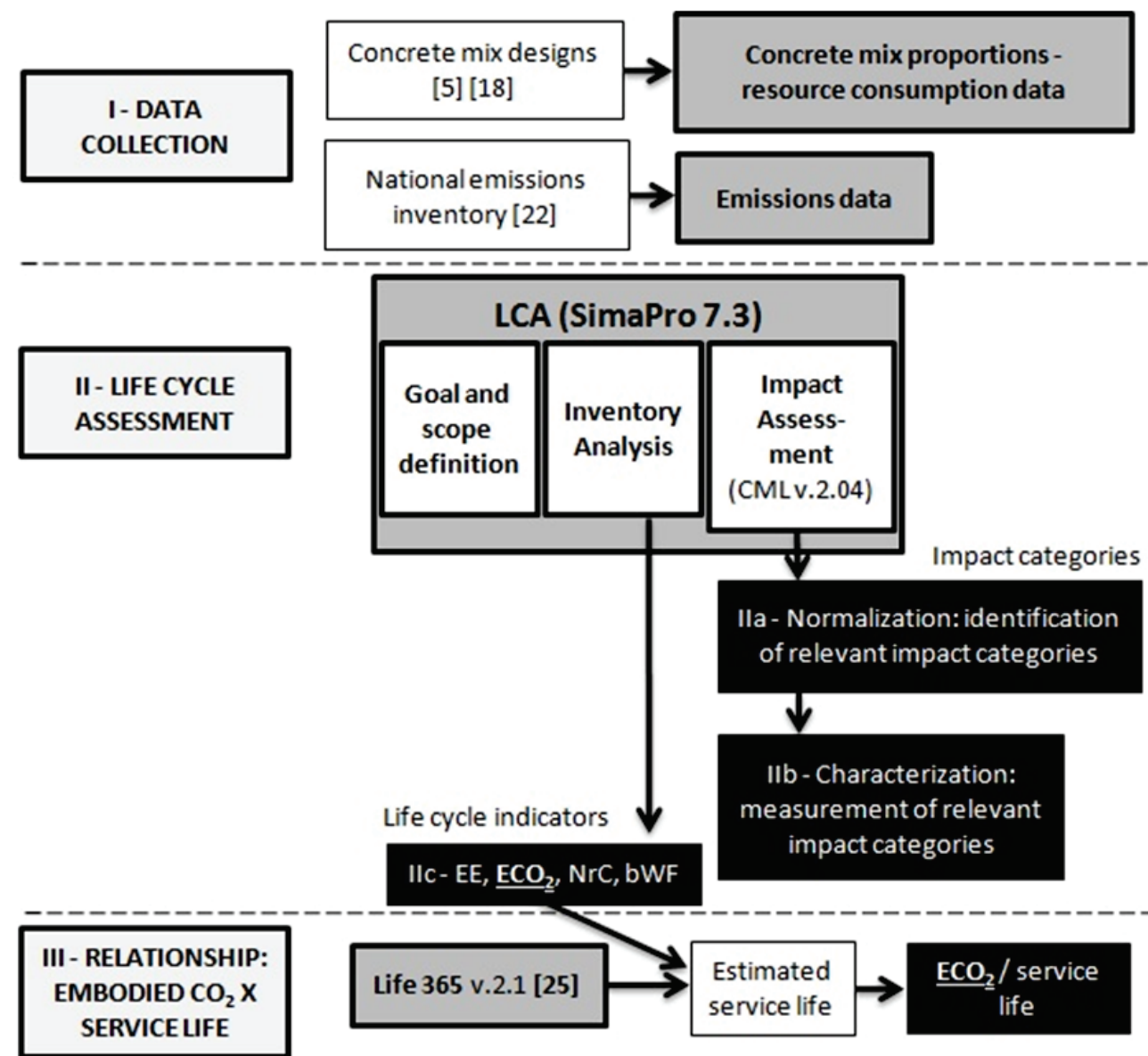

tures were used to ensure consistency of $110 \pm 20 \mathrm{~mm}$, which represents commercial practice seeking to reduce cement consumption. The very small admixture content in concretes with CP I-S-32 was considered of negligible influence and excluded from the LCA performed, in alignment with Van Den Heede and Belie [19] remarks. Table [1] shows that the studied concretes presented similar ranges of mortar content and of water to dry materials ratio. Despite their difference in consistency, such similarity assures uniformity across the main technical features governing fresh concrete's properties, allowing for comparison between them. The maximum fck obtained for concretes with CP I-S-32 (45 MPa), exceptionally limited the analysis of those concretes to that strength threshold. The percentage of ggbs, by mass, was $5 \%$ in CP I-S-32 (REGATTIERI et al [18]) and $30 \%$ and $66 \%$, respectively, in CP II-E-32 and CP III-32 (SILVA et al [6]), all of them compliant with corresponding Brazilian standards (ABNT [20]; ABNT [11]; ABNT [12]).

Though ABNT NBR 5735:1991 (ABNT [12]) allows incorporation of up to $70 \%$ of ggbs by mass to Portland cement CP III-32, commercial practice limits the maximum percentage to around $58 \%$, considered as the economic viability threshold for joint grinding of clinker and ggbs. The clinker replacement with $66 \%$ ggbs by mass considered in this paper represents a specific commercial situation, achieved through their separate grinding.

From the data expressed in Table [1], it was possible to perform the LCA (item 2.2, 2.3 and 2.4) and to estimate the service life (item 2.5) of each concrete.

\subsection{Goal and scope definition}

The most convenient functional unit to perform LCAs of concretes with different mix designs was considered to be $1 \mathrm{~m}^{3}$. This unit is commonly used in comparable studies for the material concrete. The system boundaries adopted characterize a cradle to gate analysis, which encompasses all stages - from the extraction of raw material for manufacturing to the (cement and concrete) factory's gate - but transportation and use. The support platform chosen for performing the LCA was SimaPro 7.3, which accommodates a wide range of research goals and allow database adaptation, ensuring data adherence to the context of interest.

As against the background of a sustainability assessment, a construction element must be considered in view of its functional and technical quality (Mueller [21]), the second phase of the analysis 
assessed structural components produced with the studied (material) concretes, subjected to certain exposure conditions and aiming at fulfilling a given service life. Usefulness of service life as an indicator normalizer to describe performance of reinforced concrete components is therefore investigated.

\subsection{Inventory analysis}

Modeling of Portland cement's manufacturing process uses secondary data from SILVA et al [6] and from the Brazilian inventory for greenhouse gases (GHG) associated to cement production (CARVALHO et al [22]). The mix designs listed in Table [1] were used to model concrete's manufacturing. Aggregates and water data were adapted from the Ecoinvent v.2.2 database, by switching into the Brazilian energy grid, since such processes were considered as sufficiently adherent to national practice.

During the inventory analysis the core set of life cycle environmental indicators proposed by Saade et al [23] was calculated for $1 \mathrm{~m}^{3}$ of each concrete, comprising: (i) embodied energy (EE - MJ/ $\mathrm{m}^{3}$ ), (ii) embodied $\mathrm{CO}_{2}\left(\mathrm{ECO}_{2}-\mathrm{kg} \mathrm{CO} / \mathrm{m}^{3}\right)$, (iii) blue water footprint (bWF $-\mathrm{m}^{3} / \mathrm{m}^{3}$ ) and (iv) non-renewable raw material content $\left(\mathrm{NRc}-\mathrm{kg} / \mathrm{m}^{3}\right)$.

Life cycle inventories of LCAs provide data concerning resources consumed as well as emissions and waste produced throughout all phases of the evaluated life cycle, supporting calculation of the indicators. For the EE calculation, the listed amounts of primary energy consumed from raw material extraction to manufacturing of $1 \mathrm{~m}^{3}$ of concrete were summed. Analogously, the $\mathrm{ECO}_{2}$ calculation computed all $\mathrm{CO}_{2}$ emissions listed in the inventory and disregarded other GHG gases. The bWF calculation added the water - obtained from ground and surface water sources - consumed during the extraction and production of each material/component (Hoekstra et al [24]). Finally, for NRc calculation, the consumption of all non-renewable mineral resources was totaled.

\subsection{Environmental impact analysis}

In this stage, life cycle inventory data are converted into specific impact categories inputs, covering impacts on natural resources, human health and ecosystem quality. The impact categories preset by CML 2001 v.2.04 include global warming, ozone layer depletion, human toxicity, aquatic, terrestrial and sediment ecotoxicity, land competition and oxidation, among others.

\subsection{Service life prediction}

As the concrete mix designs considered were originally developed for structures in regions potentially exposed to chloride attack, specialist

Table 1 - Characteristics of the concrete designs studied

\begin{tabular}{|c|c|c|c|c|c|c|}
\hline & $\begin{array}{c}\text { Fck } \\
(\mathrm{MPa})\end{array}$ & $\begin{array}{l}\text { Mix proportions } \\
\text { (cement:sand: } \\
\text { aggregate:water, } \\
\text { by mass) }\end{array}$ & $\begin{array}{l}\text { Cement } \\
\text { consumption } \\
\left(\mathrm{kg} / \mathrm{m}^{3}\right)\end{array}$ & $\begin{array}{c}\text { Clinker } \\
\text { consumption } \\
\left(\mathrm{kg} / \mathrm{m}^{3}\right)\end{array}$ & $\begin{array}{l}\text { Mortar } \\
\text { content } \\
(\%)\end{array}$ & $\begin{array}{l}\text { Water/dry } \\
\text { materials } \\
\text { (\%) }\end{array}$ \\
\hline \multirow{6}{*}{$\begin{array}{l}\text { Concrete with } \\
\text { Portland cement } \\
\text { CP I-S-32* }\end{array}$} & 25 & 1: 3.289: 2.80: 0.57 & 315 & 287 & 60.50 & 8.04 \\
\hline & 30 & 1: 2.90: 2.50: 0.5 & 350 & 319 & 60.94 & 7.81 \\
\hline & 35 & 1: 2.458: 2.09: 0.45 & 400 & 364 & 62.33 & 8.11 \\
\hline & 40 & 1: $2.16: 1.84: 0.4$ & 450 & 410 & 63.20 & 8.00 \\
\hline & 45 & 1: 1.863: 1.587: 0.36 & 520 & 473 & 6434 & 8.09 \\
\hline & 25 & 1: $2.719: 2.510: 0.55$ & 350 & 231 & 59.70 & 8.83 \\
\hline \multirow{7}{*}{$\begin{array}{l}\text { Concrete with } \\
\text { Portland cement } \\
\text { CP II-E-32**}\end{array}$} & 30 & 1: 2.4: $2.2: 0.5$ & 390 & 257 & 60.71 & 8.93 \\
\hline & 35 & 1: 2.24: 1.74: 0.44 & 435 & 287 & 65.06 & 8.84 \\
\hline & 40 & 1: 1.98: 1.43: 0.39 & 492 & 325 & 67.57 & 8.84 \\
\hline & 45 & 1: 1.456: $1.344: 0.33$ & 555 & 366 & 64.63 & 8.68 \\
\hline & 50 & 1: 1.352: 1.248: 0.29 & 605 & 399 & 65.33 & 8.06 \\
\hline & 55 & 1: 0.936: 0.864: 0.24 & 705 & 465 & 69.14 & 8.57 \\
\hline & 60 & 1: 0.832: 0.768: 0.21 & 770 & 508 & 70.46 & 8.08 \\
\hline \multirow{8}{*}{$\begin{array}{l}\text { Concrete with } \\
\text { Portland cement } \\
\text { CP III-32** }\end{array}$} & 25 & 1: 3.38: 3.12: 0.67 & 300 & 90 & 58.40 & 8.93 \\
\hline & 30 & 1: 2.5: 2.3: 0.5 & 380 & 114 & 60.34 & 8.62 \\
\hline & 35 & 1: 2.44: 2.25: 0.5 & 390 & 117 & 60.46 & 8.79 \\
\hline & 40 & 1: 2.34: 2.16: 0.49 & 400 & 120 & 60.73 & 8.91 \\
\hline & 45 & 1: 2.24: $2.06: 0.46$ & 425 & 128 & 61.13 & 8.68 \\
\hline & 50 & 1: 1.875: 1.725: 0.4 & 480 & 144 & 62.50 & 8.70 \\
\hline & 55 & 1: 1.768: 1.63: 0.375 & 500 & 150 & 62.94 & 8.53 \\
\hline & 60 & 1: 1.559: 1.441: 0.34 & 540 & 162 & 63.98 & 8.50 \\
\hline
\end{tabular}


Life 365 v.2.1 software supported service life prediction of hypothetical reinforced concrete structural elements using those mixtures.

The software assumes that the corrosion mechanism by chloride attack is divided in initiation and propagation periods. The initiation period corresponds to the time until sufficient chlorides penetrate the concrete cover. It is a function of the concrete cover's quality and thickness, exposure conditions and chloride concentration threshold to trigger the corrosion process. To predict the initiation period, a simplified approach assumes that the concrete is completely saturated and that ionic diffusion is the only chloride transport mechanism, governed by Fick's second diffusion Law (Equation [1]).

$$
\frac{\mathrm{dC}}{\mathrm{dt}}=\mathrm{D} \cdot \frac{\mathrm{d}^{2} \mathrm{C}}{\mathrm{dx}^{2}}
$$

where $D$ is the apparent diffusion coefficient; $C$ is the chloride amount; $x$ is the depth measured from the external surface; and $t$ is time.

The diffusion coefficient is a function of time and temperature, calculated by Equation [2].

$$
D(t)=D_{\text {ref }} \cdot\left(\frac{t_{\text {ref }}}{t}\right)^{m}
$$

where $D(t)$ is the diffusion coefficient at time $t$ (assumed as $\leq 25$ years by Life- 365 software); $D_{\text {ref }}$ is the diffusion coefficient at time $t_{\text {ref }}$ (assumed as 28 days by Life-365 software); $m$ is the diffusion decay index, a constant.

The software selects $D_{\text {ref }}$ and $m$ based on mixture design details, such as water/cementitious materials ratio and on type and proportion of cementitious materials. Corrosion initiation time is calculated by finite difference method to solve Equation [1], where $D$ value is modified at each time increment using Equation [2]. It is assumed that: (a) the material is homogeneous; (b) superficial chloride concentration around the concrete element is constant for any given point in time; (c) the element's properties are constant during each time interval; and (d) the diffusion constant is uniform throughout the element's depth (Ehlen [25]).

The default propagation period is 6 years, but can be changed to reflect local specificities. This way, actual data input is the software current version is limited to type and dimensions of the given structural element, temperature and chloride exposure conditions, concrete mix proportions, reinforcement steel type and its percentage in the element's transversal section (Ehlen [25]).

In this paper, hypothetical linear elements $(300-\mathrm{cm}$ long, with a square cross section of $30 \times 30 \mathrm{~cm}$ ) are submitted to Class III exposure condition according to ABNT NBR 6118:2007 (ABNT [26]). A minimum concrete cover of $3 \mathrm{~cm}$ was adopted, which corresponds to a nominal coverage of $4 \mathrm{~cm}$, considering a $1 \mathrm{~cm}$ tolerance. Input temperatures were monthly averages taken from the EPW (Energyplus Weather Data) file for the city of Vitoria, Brazil.

\subsection{Results analysis}

Results interpretation is performed in two main phases: (1) evaluation of environmental impacts categories associated to the production of one cubic meter; and calculation of four life cycle environmental indicators for each of the studied concrete design mixes; and (2) assessment of impacts per year of service life of structural elements using those concretes.

In the first step, values for all impact categories encompassed by CML 2001 v.2.04 are calculated and the categories that stand out after normalization stage are listed. For better visualization (Van

Figure 2 - Characterized values for the most relevant impact categories associated to concrete with CP I-S-32

\section{Concrete with CP I-S-32}

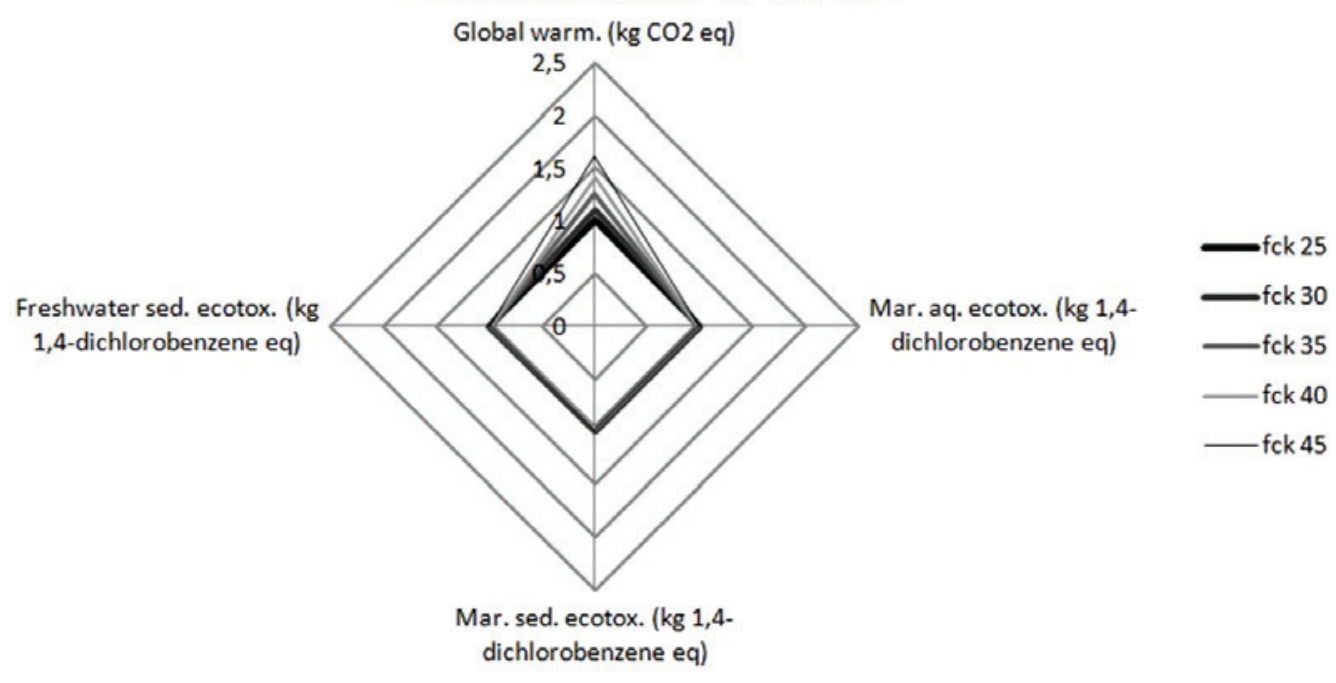




\section{Figure 3 - Characterized values for the most relevant impact categories} associated to $1 \mathrm{~m}^{3}$ of concrete with CP II-E-32

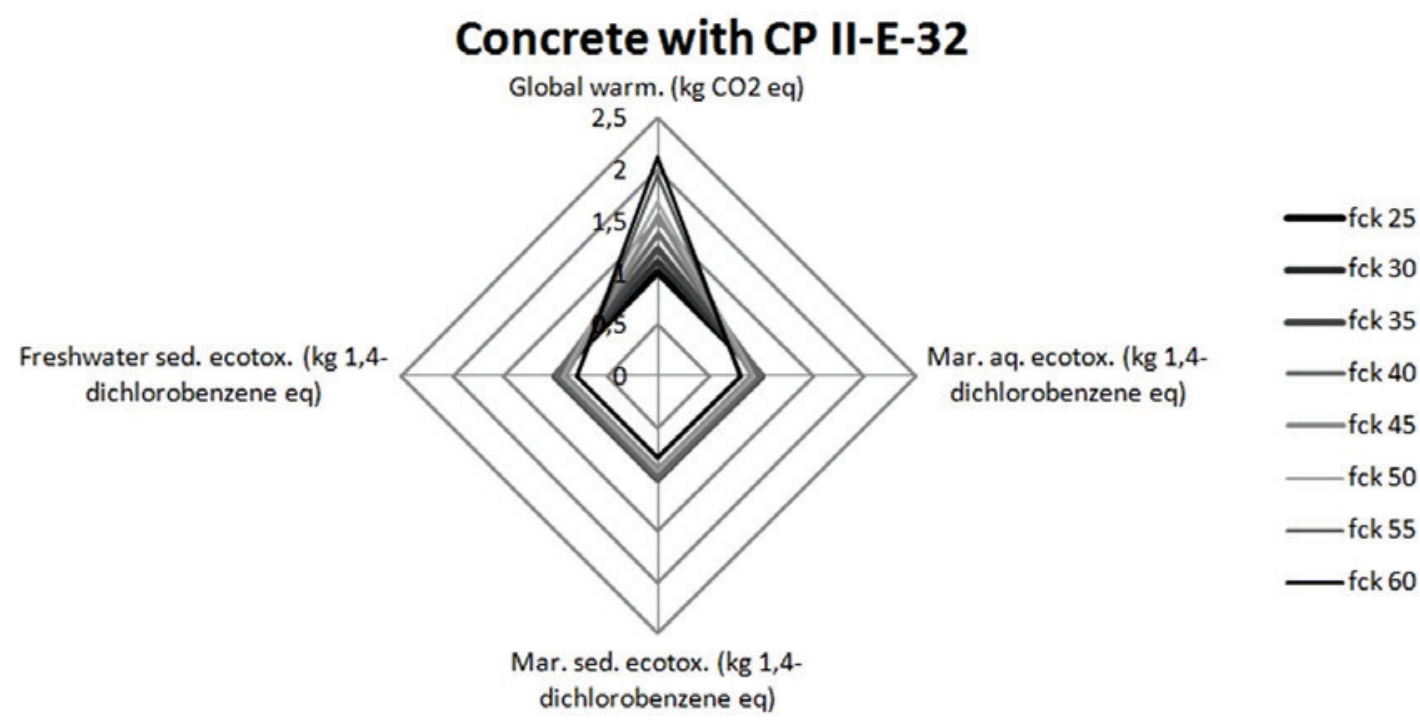

Den Heede and Belie [19]; Mueller [21]), concrete with fck $25 \mathrm{MPa}$ is taken as reference and, for each impact category, results obtained for the different mix designs are normalized in relation to values obtained for concretes with fck 25|CP I-S-32 (Figure [2]), fck 25|CP II-E-32 (Figure [3]) and fck 25|CP III-32 (Figure [4]). Next, the selected life cycle environmental indicators (embodied energy, embodied carbon, blue water footprint and non-renewable content) are calculated for all concrete design mixes, in order to provide values that are more easily communicated to and understood by designers and contractors.

Finally, the relationship between environmental impact and concrete's service life is illustrated through application to the embodied $\mathrm{CO}_{2}$ indicator. The authors chose to limit the impact/service life analysis carried out here since the "global warming" impact category is a well-known environmental liability that arises from cement and concrete production and - in their particular manufac-

Figure 4 - Characterized values for the most relevant impact categories associated to $1 \mathrm{~m}^{3}$ of concrete with CP III-32

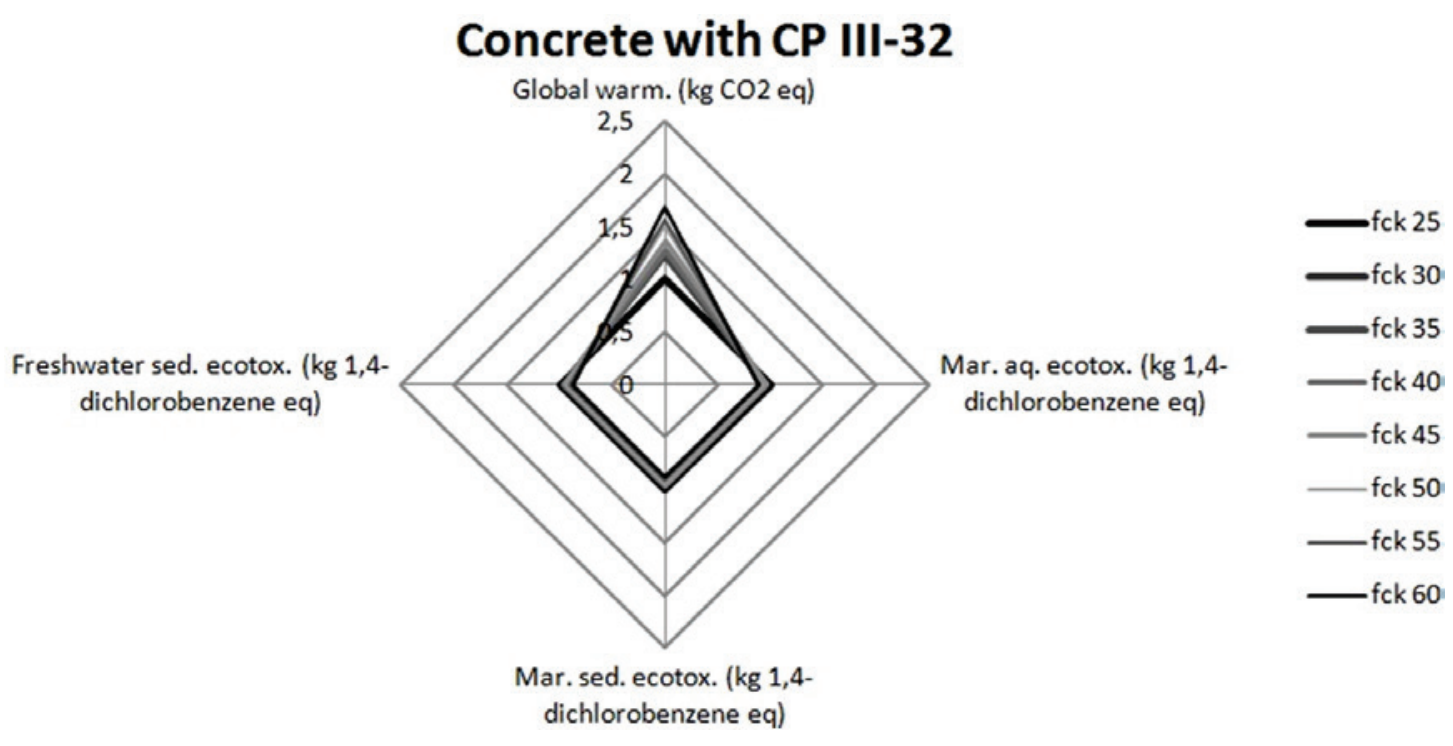






turing processes $-\mathrm{CO}_{2}$ emissions are the main contributors to that impact. Detailed analysis and discussion of the remaining environmental impact categories and indicators mentioned are targeted by parallel studies in a larger research project, being therefore out of the scope of this paper.

\section{Results and discussions}

\subsection{Characterization of the most relevant environmental impact categories}

Normalization revealed that the most relevant impact categories for production of all types of concrete studied were (i) global warming, (ii) marine aquatic ecotoxicity, (iii) marine sediment ecotoxicity,

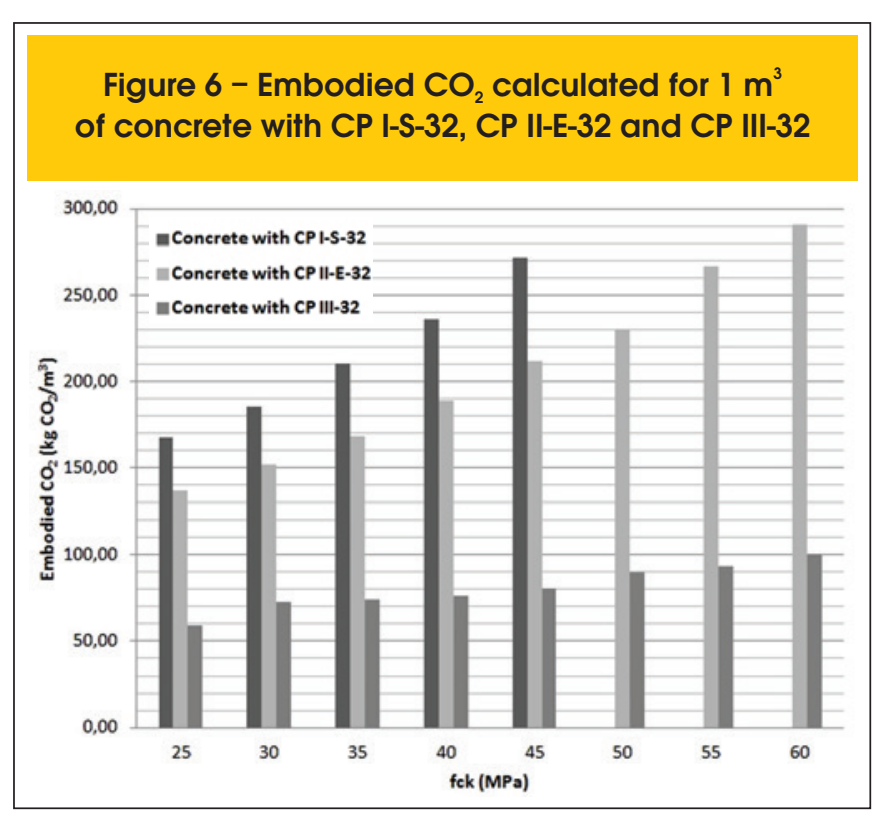

Figure 7 - Blue water footprint calculated for $1 \mathrm{~m}^{3}$ of concrete with CP I-S-32, CP II-E-32 and CP III-32

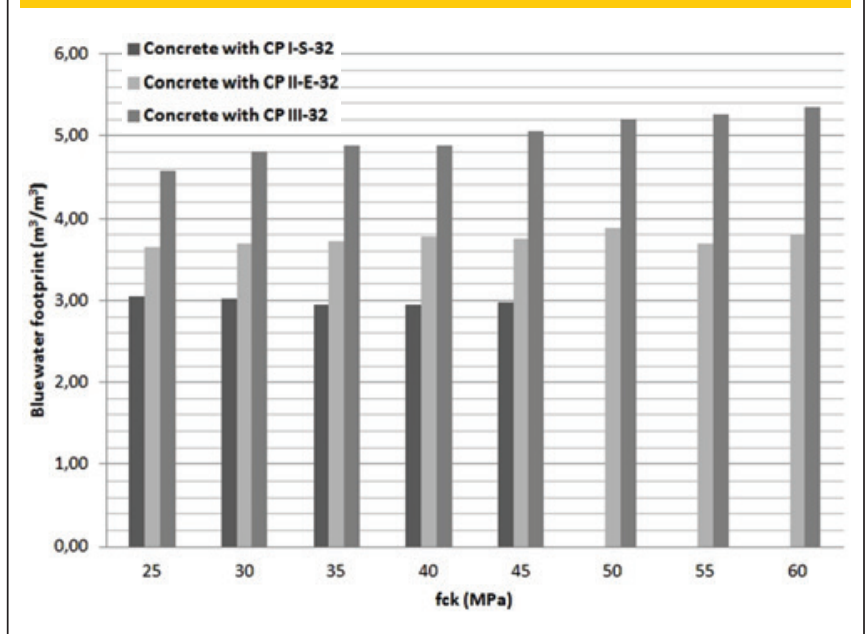

and (iv) freshwater sediment ecotoxicity. The analysis was limited to the characterized values found for a 100-year time boundary, set as default by the impact assessment method (Figures [2], [3] and [4]).

As expected from previous scientific publications, comparison across Figures [2], [3] and [4] highlights that concretes using blended cements have lower GWP than the reference concrete. Furthermore, fck increase (which, for the cases studied, is obtained through higher cement - and clinker - consumption) also intensifies GWP, but at a significantly lower rate for concretes with ggbs substitution for clinker in cement. Since clinker production does not contribute as significantly to ecotoxicity as its $\mathrm{CO}_{2}$ emissions do to global warming, and since such contribution seems

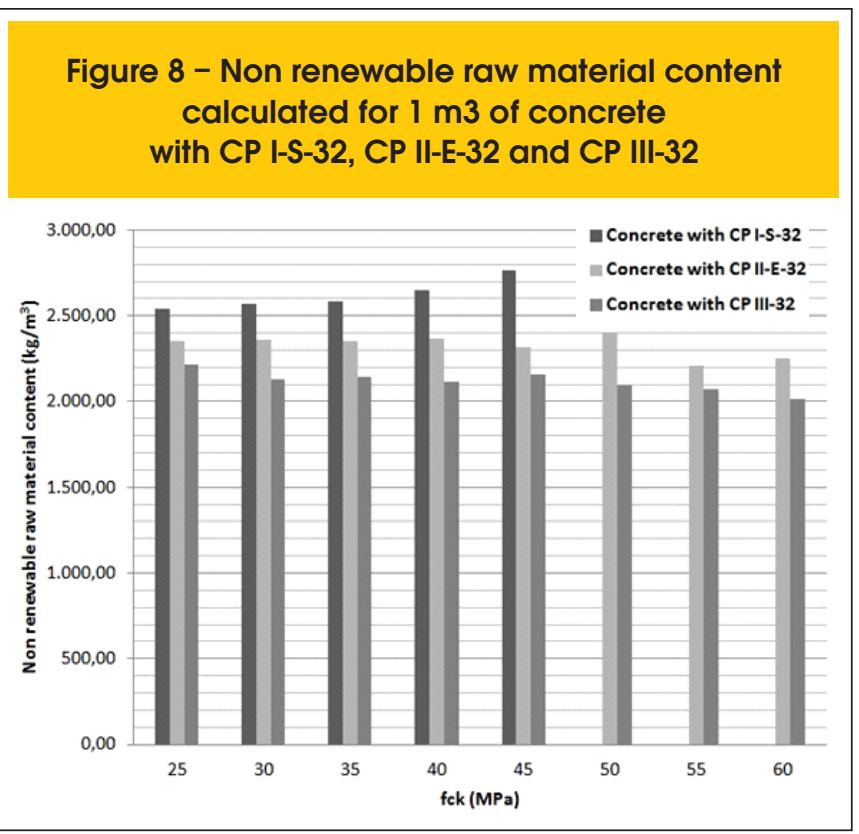


Table 2 - Variations on each indicator's values for every $1 \%$ replacement of clinker with ggbs

\begin{tabular}{|c|c|c|c|c|c|c|c|c|}
\hline \multirow[b]{2}{*}{ Concrete with CP I-S-32 } & \multicolumn{2}{|c|}{$\begin{array}{l}\text { Embodied } \\
\text { energy }\left(\mathrm{MJ} / \mathrm{m}^{3}\right)\end{array}$} & \multicolumn{2}{|c|}{$\begin{array}{l}\text { Embodied } \mathrm{CO}_{2} \\
\left(\mathrm{~kg} \mathrm{CO} / \mathrm{m}^{3}\right)\end{array}$} & \multicolumn{2}{|c|}{$\begin{array}{c}\text { Blue water } \\
\text { footprint }\left(\mathrm{m}^{3} / \mathrm{m}^{3}\right)\end{array}$} & \multicolumn{2}{|c|}{$\begin{array}{l}\text { Non renewable } \\
\text { content }\left(\mathrm{kg} / \mathrm{m}^{3}\right)\end{array}$} \\
\hline & fck 25 & fck 45 & fck 25 & fck 45 & fck 25 & fck 45 & fck 25 & fck 45 \\
\hline to concrete with CP III-32 & $-1.05 \%$ & $-1.15 \%$ & $-1.06 \%$ & $-1.15 \%$ & $+0.82 \%$ & $+1.15 \%$ & $-0.21 \%$ & $-0.36 \%$ \\
\hline Concrete with CP II-E-32 & fck 25 & fck 60 & fck 25 & fck 60 & fck 25 & fck 60 & fck 25 & fck 60 \\
\hline to concrete with CP III-32 & $-0.92 \%$ & $-1.07 \%$ & $-0.93 \%$ & $-1.08 \%$ & $+0.41 \%$ & $+0.67 \%$ & $-0.09 \%$ & $-0.17 \%$ \\
\hline
\end{tabular}

to be similar to that of ggbs, the ecotoxicity impact values slightly reduce with the increase in fck, but at a negligible rate.

\subsection{Calculation of life cycle environmental indicators}

Figures [5], [6], [7] and [8] present the calculated values of the selected life cycle environmental indicators.

Values of embodied $\mathrm{CO}_{2}$, embodied energy and non-renewable raw material content indicators diminish considerably and progressively with the increase in ggbs as clinker replacement from $5 \%$ (CP I-S-32) to $30 \%$ (CP II-E-32) and to $66 \%$ (CP III-32). These results corroborate the environmental advantages of replacing clinker with ggbs in cement/concrete manufacturing pointed out by authors like Isaia and Gastaldini [8], Van Den Heede and Belie [19], Buffenbarger [9], Van Geem [10] and Mueller [21].

The only exception was the blue water footprint indicator, which conversely rises when shifting from concrete with CP I-S-32 to concrete with CP III-32. The observed raise results from the water intensive blast furnace slag granulation process. Most steelmaking companies environmental management programs have implemented water reuse practices. Such procedures were not considered in this paper, as their variation challenges configuration of an average industry practice to be accounted for in the LCA modeling. Table [2] shows the variations on each indicator's values for every $1 \%$ replacement of clinker with ggbs. The resulting benefit in terms of embodied energy $(0,92 \%-1,15 \%)$ is higher than international

Table 3 - Estimated service life (in years) of analyzed concretes

\begin{tabular}{|cccc|}
$\begin{array}{c}\text { Fck } \\
(\mathrm{MPa})\end{array}$ & $\begin{array}{c}\text { Concrete with } \\
\text { CP I-S-32 }\end{array}$ & $\begin{array}{c}\text { Concrete with } \\
\text { CP I-E-32 }\end{array}$ & $\begin{array}{c}\text { Concrete with } \\
\text { CP III-32 }\end{array}$ \\
\hline C25 & 9.2 & 10.2 & 11.6 \\
C30 & 9.8 & 11 & 14.4 \\
C35 & 10.4 & 12.1 & 14.4 \\
C40 & 11.1 & 13.2 & 14.8 \\
C45 & 11.8 & 15.2 & 16.1 \\
C50 & - & 16.8 & 19.6 \\
C55 & - & 18.8 & 21.4 \\
C60 & - & 18.8 & 24.6 \\
\hline
\end{tabular}

SCM's average $(-0,7 \%$, reported by Van Geem [10]). International reference values for the other environmental indicators investigated were not fount at the time of writing, but would probably follow this trend.

\subsection{Relationship between embodied $\mathrm{CO}_{2}$ and concrete's service life}

Table [3] presents the service life estimated by software Life 365 v.2.1 for each type of concrete studied.

Figure [9] uses those data to normalize the mass of $\mathrm{CO}_{2}$ embodied in $1 \mathrm{~m}^{3}$ of each concrete per year of its service life. These results disregard the potential downsizing of the structural elements (dematerialization) due to increased characteristic compressive strength.

Figure [9] confirms that, for any given resistance, much more $\mathrm{CO}_{2}$ is embodied in each $\mathrm{m}^{3}$ of concrete with CP I-S-32 than with CP II-E-32 and with CP III-32, at a factor that is roughly proportional to the ggbs content. Concretes with Portland cements CP II-E-32 and CP III-32 show approximately horizontal trend lines, which represent strength growth at a constant mass of embodied $\mathrm{CO}_{2}$ per $\mathrm{m}^{3}$ of concrete. Contrastingly, concretes with cement CP I-S-32 follow a steep curve, suggesting that each increase in strength comes at a much higher environmental impact increment and that service life extension (Table [3]) is not able to neutralize the additional $\mathrm{CO}_{2}$ emissions resulting from the higher clinker consumption needed for increased resistance (Table [1]).

\section{Figure 9 - Relationship between the embodied $\mathrm{CO}_{2}$ per $\mathrm{m}^{3}$ and the service life of each type of concrete}

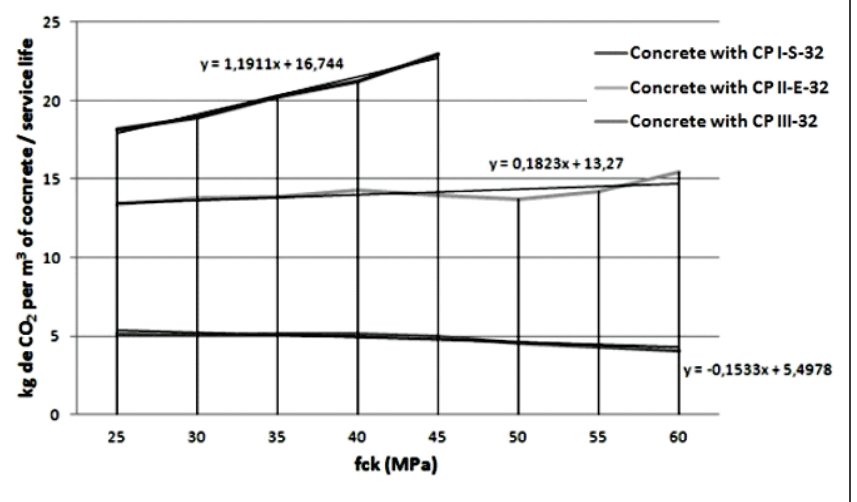




\section{Final considerations}

Normalization revealed that global warming and ecotoxicity (marine aquatic, marine sediment and freshwater sediment) are the most relevant impact categories for the concretes modeled. Concretes using blended cements have global warming potential (GWP) significantly lower than the reference concrete. Results for global warming are very sensible to clinker content. Furthermore, fck increase based on higher cement/clinker consumption intensifies the GWP, but at a significantly lower rate for concretes with ggbs substitution for clinker in cement. On the other hand, clinker's contribution to ecotoxicity seems to be close to that of ggbs, so that values in those categories do not change much with the increase in fck.

Increasing the ggbs substitution for clinker in Portland cement reduced the overall concrete environmental loads as indicated by all metrics but blue water footprint. The benefits of such replacement seem to be higher than average international SCM's figures. Consideration of service life as a normalizer when establishing environmental indicators adds coherence to life cycle environmental performance interpretation, to simultaneously communicate concrete's environmental, functional and quality aspects.

\section{Acknowledgements}

Authors thank Companhia Paulista de Força e Luz (CPFL) and Conselho Nacional de Desenvolvimento Científico e Tecnológico (CNPq) for their financial support.

\section{References}

[01] Schneider M; Romer M; Tschudin M; Bolio H. Sustainable cement production-present and future. Cement and Concrete Research, vol. 41, 2011; p. $642-650$.

[02] Huntzinger DN; Eatmon TD. A life-cycle assessment of Portland cement manufacturing: comparing the traditional process with alternative technologies. Journal of Cleaner Production, vol. 17, 2009; p. $668-675$

[03] Cement Sustainability Initiative - CSI. Cement industry energy and $\mathrm{CO}_{2}$ performance - Getting the numbers right. 2009. Available at: < http://www.wbcsdcement. org/pdf/csi-gnr-report-with\%20label.pdf>. Access in Oct. 14, 2011

[04] Cement Sustainability Initiative - CSI. Cement - At the foundation of sustainable development. 2007. Available at: < http://www.wbcsdcement.org/pdf/csi.pdf> Access in Oct. 12, 2011.

[05] SILVA, M. G. (coordinator). Concreto de Alto Desempenho com Elevados Teores de Escória de Alto Forno: Estratégia para consolidar o Mercado da Escória de Alto Forno. Technical Report, Núcleo de Excelência em Escórias Siderúrgicas (NEXES). Centro Tecnológico, Universidade Federal do Espírito Santo, 2006.

[06] SILVA, M. G.; SILVA, V., G.; RODRIGUES, G. L. C.; POLESE, M. O. Propriedades, normalização e tendências na adição de escória de alto-forno em cimentos e concretos. Technical Report, Núcleo de Excelência em Escórias Siderúrgicas, Centro Tecnológico, Universidade Federal do Espírito Santo, 2006, p. 106.

[07] SILVA, M. G. Cimento Portland com Adições Minerais Materiais de Construção Civil e Princípios de Ciência e Engenharia de Materiais (Ed. ISAIA, G. C), $2^{a}$ Edição Atualizada e Ampliada, 2010, p.791-824.

[08] Isaia GC; Gastaldini ALG. Perspectivas ambientais e econômicas do concreto com altos teores de adições minerais: um estudo de caso. Ambiente Construído, vol. 4, 2004; p. 19-30.

[09] BUFFENBARGER, J.K. Achieving sustainability and resiliency in the built environment through the use of bended cements. In: First international conference on concrete sustainability, 1 $1^{\text {st }}$, Tokyo, 2013, Proceedings, Tokyo, May 27-29, 2013. Lead Paper. p. 73-80.

[10] Van Geem MG. Sustainability designer's notebook. $\mathrm{PCl}$ Accent, Spring 2007. Precast/Prestressed Concrete Institute. 2007

[11] Associação Brasileira de Normas Técnicas - ABNT. Cimento Portland composto. NBR 11. 578. Rio de Janeiro, 1991.

[12] Associação Brasileira de Normas Técnicas - ABNT Cimento Portland de alto-forno. NBR 5735. Rio de Janeiro, 1991.

[13] European Committee for Standardization. Sustainability of construction works - Environmental product declarations - Core rules for the product category of construction products. EN 15804:2012. Brussels, 2012.

[14] HABERT, G., BOUZIDI, Y., CHEN, C., JULLIEN, A. Resource consumption indicator for concrete construction. Concrete 21st Century super hero. In: Annual international FIB symposium, $11^{\text {th }}$, London, 2009, Proceedings, London 2009.

[15] ROUSSEL, N. RILEM activities in the field of sustainable construction and its future. In: First international conference on concrete sustainability, $1^{\text {st }}$, Tokyo, 2013, Proceedings, Tokyo, May 27-29, 2013. Lead Paper. p. 56-61

[16] International Organization for Standardization (ISO). Environmental management - Life Cycle Assessment - Requirements and Guidelines. ISO 14044, 2006.

[17] GOEDKOOP, M.; SCHRYVER, A. D.; OELE, M.; DURKSZ, S.; ROEST, D. Introduction to LCA with SimaPro 7. Amersfoort: Product Ecology Consultants, 2008. 82 p.

[18] REGATTIERI, C. E. X.; SILVA, M. G.; HELENE, $P$. Influência das adições do cimento na resistência à penetração de íons cloreto. In: Reunião do IBRACON, 41 a , Salvador, 1999.

[19] Van Den Heede P; Belie N. Environmental impact and life cycle assessment (LCA) of traditional and 'green' concretes: Literature review and theoretical calculations. Cement and Concrete Composites, vol. 32, 2012; p. 431-442.

[20] Associação Brasileira de Normas Técnicas - ABNT. Cimento Portland comum. NBR 5732. Rio de Janeiro, 1991.

[21] MUELLER, H. S.; VOGEL, M.; HAIST, M. Service life design - a tool for sustainable application of concrete. 
In: First international conference on concrete sustainability, $1^{\text {st }}$, Tokyo, 2013, Proceedings, Tokyo, May 27-29, 2013. Lead Paper. p.93-106.

[22] CARVALHO, J. O.; KIHARA, Y.; MAIA, C.; VISEDO, G., Emissões de Gases de Efeito Estufa nos Processos Industriais - Produtos Minerais (Parte 1). In: Segundo Inventário Brasileiro de Emissões e Remoções Antrópicas de Gases de Efeito Estufa, Brasilia, 2010, $37 \mathrm{p}$.

[23] SAADE, M. R. M.; SILVA, M. G.; GOMES, V. Proposition and Preliminary Analysis of a Core Set of Indicators to Describe Material Eco-Efficiency of Brazilian Buildings. In: Smart and Sustainable Built Environment, $1^{\text {st }}$, São Paulo, 2012, Proceedings, São Paulo, 2012, p.525-532.

[24] HOEKSTRA, A.Y.; CHAPAGAIN, A.K.; ALDAYA, M.M. and MEKONNEN, M.M. The water footprint assessment manual: setting the global standard. London: Earthscan Ltd., 2011.

[25] EHLEN, M. A. Life-365 Service life prediction model, v.2.1.1 - Users Manual. January, 31, 2012.

[26] Associação Brasileira de Normas Técnicas - ABNT. Projeto de estruturas de concreto armado Procedimento. NBR 6118. Rio de Janeiro, 2007. 